Supporting Information:

\title{
Photochemical Modeling of Emissions Trading of Highly Reactive Volatile Organic Compounds (HRVOCs) in Houston, Texas.
}

\section{Part 1. Reactivity Based Trading and Potential for Ozone Hot Spot}

Formation

\author{
LINLIN WANG, \\ TAMMY THOMPSON, \\ ELENA C. MCDONALD-BULLER, \\ ALBA WEBB, \\ DAVID T. ALLEN \\ Center for Energy and Environmental Resources, \\ The University of Texas at Austin, \\ 10100 Burnet Road, Mail Code R7100 \\ Austin, Texas, 78758, USA \\ Environmental Science \& Technology
}

Section S-1: $\quad$ Summary of performance of modeling configuration in predicting ozone concentrations in an historical episode

Section S-2: $\quad$ Emission inventories for 25 key accounts for base case attainment demonstration

Section S-3: $\quad$ Method for calculating Relative Reduction Factors (RRFs)

Section S-4: $\quad$ Reactivity weighted emission inventories for 25 key accounts

Section S-5: Impacts of industrial point source VOC emissions on ozone concentrations in base case attainment demonstration

Section S-6: $\quad$ Air quality metrics for HRVOC trading between regions

Section S-7: $\quad$ Air quality metrics for trading of other-VOCs for HRVOCs 


\section{Section S-1: Summary of performance of modeling configuration in predicting ozone concentrations in an historical episode}

The modeling configuration used in this work was developed by the Texas Commission on Environmental Quality and its contractors, and has been used in the evaluation of air quality regulations in the Houston-Galveston-Brazoria area. The model inputs and the overall model performance, based on EPA criteria, are described in detail in references 5 and 8 . The four Figures shown below (S1-S5) are drawn from the performance evaluation documents and provide an indication of the overall performance of the model. Figures S1-S4 show predicted and measured ozone concentrations for specific days of the episode, while Figure S5 compares predicted and observed 8-hour average ozone concentrations at multiple sites in the region.

Figure S1. Predicted and observed maximum ozone concentrations for $8 / 25 / 2000^{5,8}$

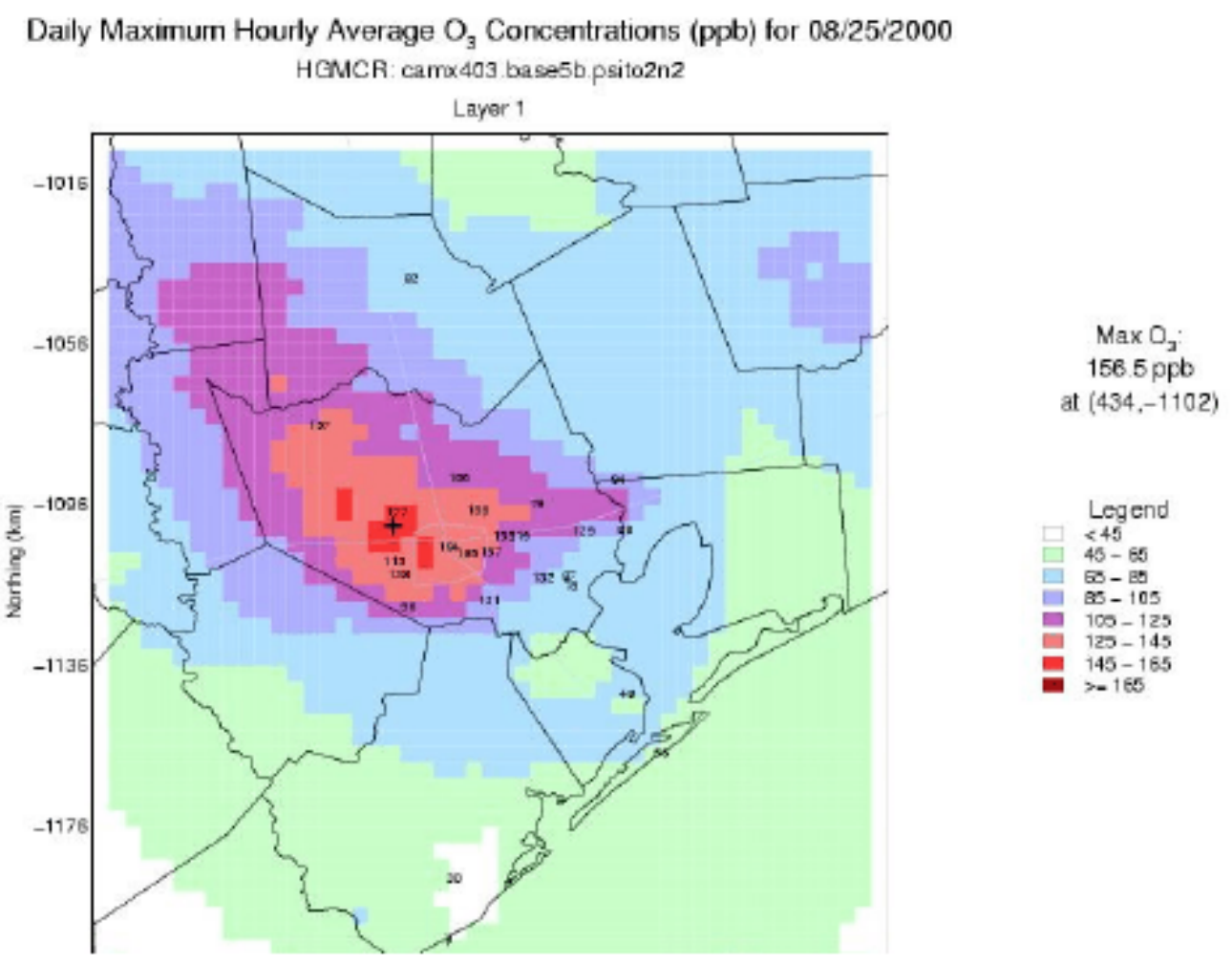


Figure S2. Predicted and observed maximum ozone concentrations for 8/30/2000

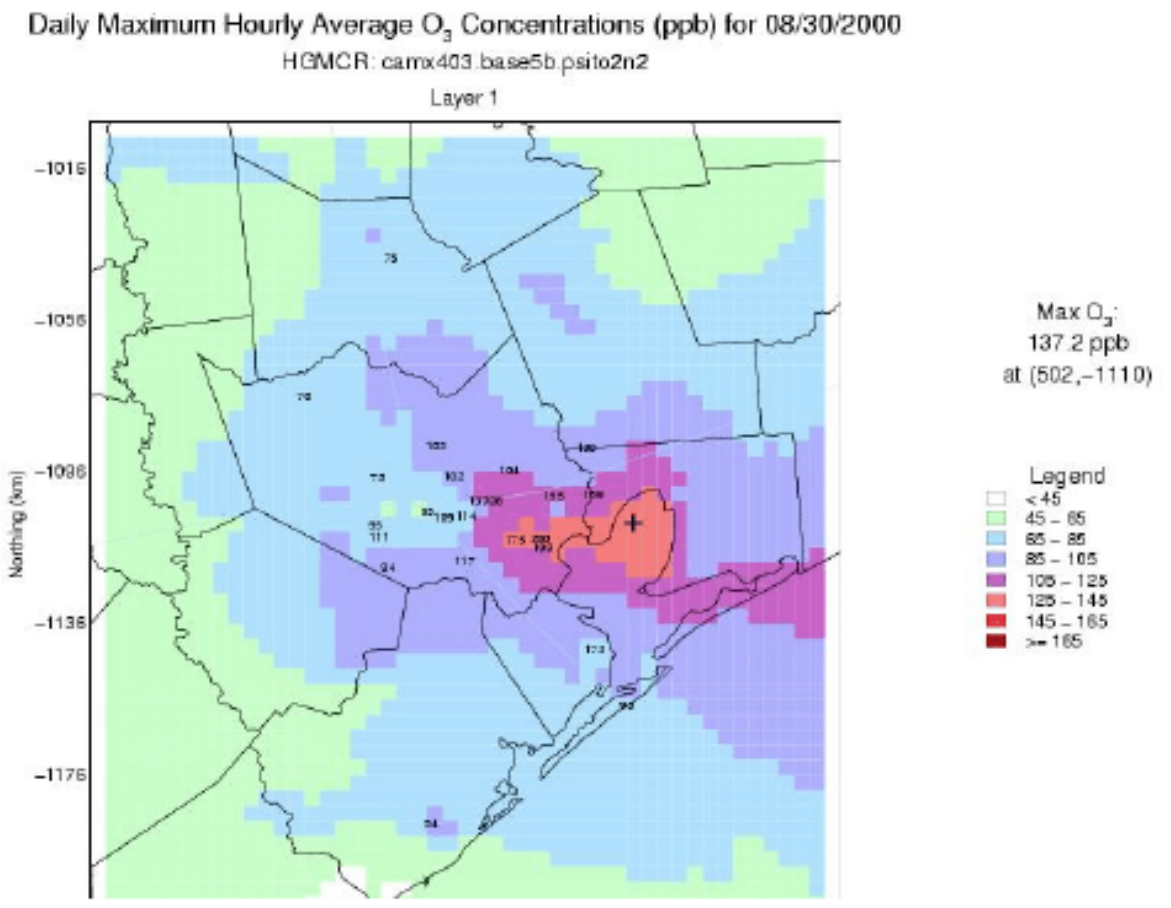

Figure S3. Predicted and observed maximum ozone concentrations for 8/31/2000,8

Daily Maximum Hourly Average $\mathrm{O}_{\mathrm{y}}$ Concentrations (ppb) for 08/31/2000 HGMCR: carrx 403.base5b.psito2n2

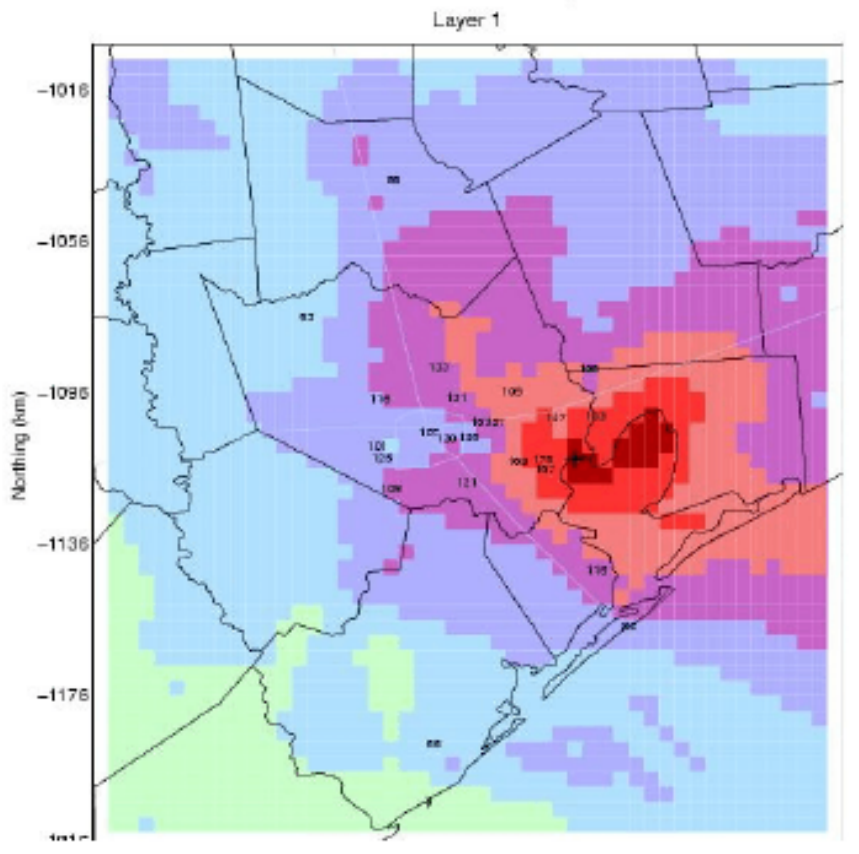

$$
\begin{aligned}
& \mathrm{MaxO}_{3} \\
& 173.0 \mathrm{ppb} \\
& \text { at }(480,-1114) \\
& \begin{array}{l}
\text { Legend } \\
<45 \\
45-66 \\
05-85 \\
85-105 \\
105-125 \\
125-145 \\
145-165 \\
0=165
\end{array}
\end{aligned}
$$


Figure S4. Predicted and observed maximum ozone concentrations for 9/2/2000 Daily Maximum Hourly Average $\mathrm{O}_{3}$ Concentrations (ppb) for 09/02/2000

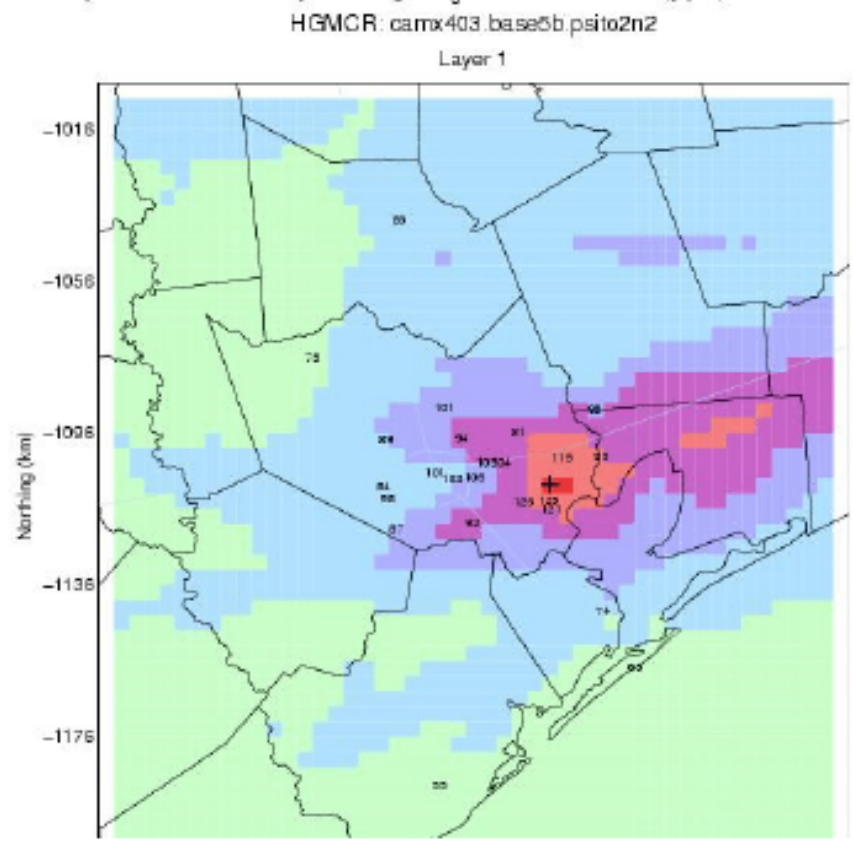

$$
\begin{gathered}
\operatorname{Max} O_{3} \\
152.7 \mathrm{ppb} \\
\text { at }(47 \mathrm{~B},-1110) \\
\\
\\
\text { Legend } \\
<45 \\
43-65 \\
80-85 \\
80-105 \\
105-125 \\
125-145 \\
145-185 \\
>-165
\end{gathered}
$$

Figure S5. Predicted and observed 8-hour averaged ozone concentrations at multiple sites ${ }^{5,8}$

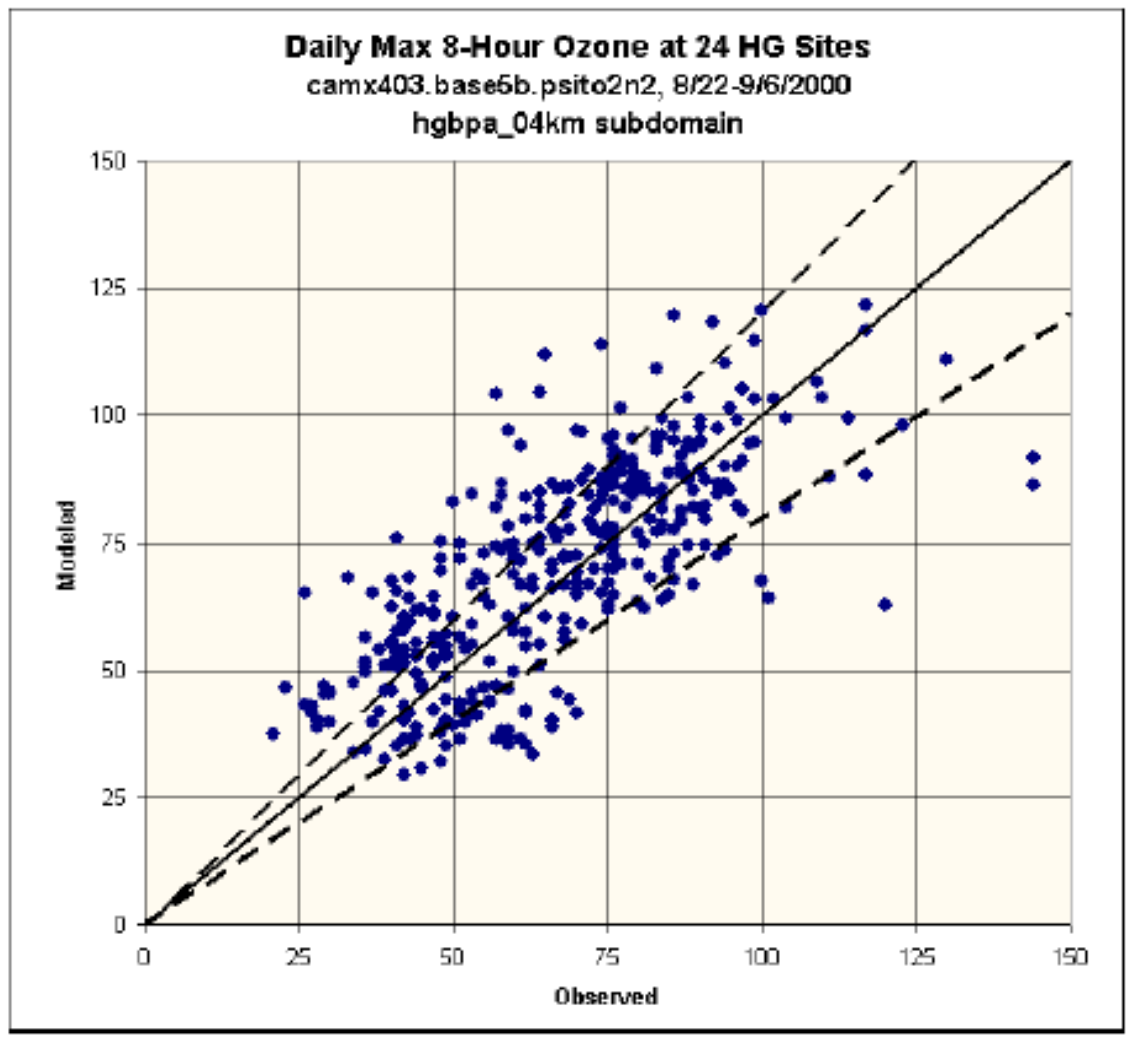




\begin{tabular}{|c|c|}
\hline VOC Species & Fraction \\
\hline Propene & $12.70 \%$ \\
\hline Ethylene & $11.04 \%$ \\
\hline isomers of pentane & $6.01 \%$ \\
\hline n-butane & $5.72 \%$ \\
\hline isomers of butane & $4.97 \%$ \\
\hline Propane & $4.85 \%$ \\
\hline Isobutene & $4.41 \%$ \\
\hline Hexane & $3.62 \%$ \\
\hline 1-pentene & $2.48 \%$ \\
\hline Benzene & $2.36 \%$ \\
\hline Isopentane & $2.25 \%$ \\
\hline 1,3-butadiene & $2.14 \%$ \\
\hline n-pentane & $2.10 \%$ \\
\hline 1-hexene & $2.05 \%$ \\
\hline Butane & $1.98 \%$ \\
\hline Formaldehyde & $1.88 \%$ \\
\hline Heptane & $1.62 \%$ \\
\hline Toluene & $1.59 \%$ \\
\hline 2-methylpentane & $1.46 \%$ \\
\hline Methyl alcohol & $1.44 \%$ \\
\hline $\begin{array}{l}\text { Methyl-t-butyl } \\
\text { ether }\end{array}$ & $1.38 \%$ \\
\hline Isobutylene & $1.14 \%$ \\
\hline Isoprene & $1.14 \%$ \\
\hline adipic acid & $1.11 \%$ \\
\hline isomers of hexane & $0.78 \%$ \\
\hline methylethyl ketone & $0.65 \%$ \\
\hline isopropyl alcohol & $0.58 \%$ \\
\hline Ethylbenzene & $0.54 \%$ \\
\hline n-dodecane & $0.52 \%$ \\
\hline isomers of xylene & $0.51 \%$ \\
\hline Cyclohexane & $0.50 \%$ \\
\hline Chlorobenzene & $0.47 \%$ \\
\hline n-decane & $0.44 \%$ \\
\hline 2-methyl-1-butene & $0.41 \%$ \\
\hline vinyl acetate & $0.40 \%$ \\
\hline Octane & $0.40 \%$ \\
\hline n-tridecane & $0.40 \%$ \\
\hline n-undecane & $0.38 \%$ \\
\hline c7 cycloparaffins & $0.37 \%$ \\
\hline Styrene & $0.35 \%$ \\
\hline 2,2-dimethylbutane & $0.34 \%$ \\
\hline Pentadiene & $0.33 \%$ \\
\hline Acetylene & $0.30 \%$ \\
\hline $\begin{array}{l}375 \text { other known } \\
\text { VOC species }\end{array}$ & $10.00 \%$ \\
\hline Total & $100.00 \%$ \\
\hline
\end{tabular}

\section{Section S-2: Emission inventories for 25 key accounts for base case attainment demonstration}

Tables S1 to S4 characterize the emissions of VOCs, HRVOCs, and NOx at the 25 facilities that were considered in the trading scenarios. Details concerning other aspects of the emission inventory are available in references 5 and 8.

Table S1 (left): The factional contribution of major VOC species to VOC point source emissions of top 25 accounts participating in the trading program in the Houston/Galveston 8-county area in 2007, when attainment is achieved (base case attainment demonstration inventory) 


\begin{tabular}{|c|c|c|c|c|c|c|c|}
\hline \multirow[b]{2}{*}{ Facility Number } & \multicolumn{4}{|c|}{ Before control } & \multicolumn{3}{|c|}{ Allocation after control } \\
\hline & Stack & Flare & Fugitive & Total & Stack+Flare & Fugitive & Total \\
\hline & (tons/day) & (tons/day) & (tons/day) & (tons/day) & (tons/day) & (tons/day) & (tons/day) \\
\hline 1 & 2.38 & 4.24 & 18.30 & 24.91 & 1.49 & 6.59 & 8.08 \\
\hline 2 & 8.10 & 2.71 & 12.52 & 23.33 & 7.09 & 4.51 & 11.60 \\
\hline 3 & 0.09 & 4.14 & 5.52 & 9.75 & 0.89 & 1.99 & 2.88 \\
\hline 4 & 0.59 & 6.03 & 1.33 & 7.94 & 1.60 & 0.48 & 2.08 \\
\hline 5 & 1.37 & 2.81 & 1.55 & 5.73 & 1.41 & 0.56 & 1.96 \\
\hline 6 & 0.27 & 3.16 & 2.20 & 5.63 & 0.86 & 0.79 & 1.66 \\
\hline 7 & 2.11 & 0.99 & 4.20 & 7.30 & 0.76 & 1.51 & 2.27 \\
\hline 8 & 2.75 & 0.19 & 4.94 & 7.88 & 0.62 & 1.78 & 2.40 \\
\hline 9 & 6.38 & 0.14 & 0.07 & 6.59 & 1.28 & 0.02 & 1.30 \\
\hline 10 & 5.91 & 0.30 & 6.88 & 13.09 & 5.70 & 2.48 & 8.18 \\
\hline 11 & 0.20 & 1.41 & 0.80 & 2.41 & 0.21 & 0.29 & 0.50 \\
\hline 12 & 0.22 & 0.95 & 2.65 & 3.82 & 0.31 & 0.95 & 1.26 \\
\hline 13 & 0.15 & 1.25 & 1.26 & 2.65 & 0.31 & 0.45 & 0.76 \\
\hline 14 & 0.20 & 1.30 & 1.10 & 2.60 & 0.28 & 0.40 & 0.68 \\
\hline 15 & 0.91 & 0.94 & 0.66 & 2.51 & 0.19 & 0.24 & 0.42 \\
\hline 16 & 0.27 & 1.55 & 0.98 & 2.80 & 0.89 & 0.35 & 1.25 \\
\hline 17 & 9.41 & 6.21 & 5.73 & 21.35 & 14.73 & 2.06 & 16.80 \\
\hline 18 & 0.62 & 1.22 & 1.17 & 3.01 & 1.25 & 0.42 & 1.67 \\
\hline 19 & 0.02 & 0.20 & 2.18 & 2.40 & 0.07 & 0.78 & 0.85 \\
\hline 20 & 1.18 & 1.58 & 1.24 & 4.00 & 1.43 & 0.45 & 1.87 \\
\hline 21 & 1.59 & 0.00 & 0.48 & 2.07 & 0.22 & 0.17 & 0.39 \\
\hline 22 & 1.15 & 0.19 & 1.32 & 2.65 & 0.68 & 0.47 & 1.15 \\
\hline 23 & 1.30 & 0.36 & 0.56 & 2.22 & 0.89 & 0.20 & 1.09 \\
\hline 24 & 1.82 & 0.01 & 2.23 & 4.07 & 1.38 & 0.80 & 2.18 \\
\hline 25 & 0.81 & 0.22 & 0.76 & 1.79 & 0.58 & 0.27 & 0.85 \\
\hline Subtotal & 49.80 & 42.09 & 80.62 & 172.51 & 45.12 & 29.02 & 74.14 \\
\hline Fraction & $28.87 \%$ & $24.40 \%$ & $46.73 \%$ & & $60.85 \%$ & $39.15 \%$ & \\
\hline
\end{tabular}

Table S2 Stack and flare (non-fugitive) and fugitive VOC emissions at 25 capped accounts, before and after the caps are applied 
Table S3 Stack and flare (non-fugitive) and fugitive HRVOC emissions at 25 capped accounts, before and after the caps are applied

\begin{tabular}{|c|c|c|c|c|c|c|c|}
\hline \multirow[b]{2}{*}{ Facility Number } & \multicolumn{4}{|c|}{ Before control } & \multicolumn{3}{|c|}{ Allocation after control } \\
\hline & Stack & Flare & Fugitive & Total & Stack+Flare & Fugitive & Total \\
\hline & (tons/day) & (tons/day) & (tons/day) & (tons/day) & (tons/day) & (tons/day) & (tons/day) \\
\hline 1 & 2.38 & 3.32 & 15.50 & 19.87 & 0.57 & 5.58 & 6.15 \\
\hline 2 & 2.42 & 1.72 & 7.71 & 11.85 & 0.41 & 2.78 & 3.19 \\
\hline 3 & 0.05 & 3.66 & 4.24 & 7.95 & 0.37 & 1.53 & 1.90 \\
\hline 4 & 0.49 & 5.08 & 1.04 & 6.62 & 0.56 & 0.38 & 0.93 \\
\hline 5 & 0.66 & 2.43 & 0.99 & 4.08 & 0.31 & 0.36 & 0.67 \\
\hline 6 & 0.04 & 2.82 & 1.94 & 4.79 & 0.29 & 0.70 & 0.98 \\
\hline 7 & 1.77 & 0.84 & 3.99 & 6.60 & 0.26 & 1.44 & 1.70 \\
\hline 8 & 2.42 & 0.16 & 4.77 & 7.34 & 0.26 & 1.72 & 1.97 \\
\hline 9 & 5.83 & 0.00 & 0.00 & 5.83 & 0.58 & 0.00 & 0.58 \\
\hline 10 & 0.34 & 0.23 & 3.47 & 4.04 & 0.06 & 1.25 & 1.31 \\
\hline 11 & 0.15 & 1.40 & 0.75 & 2.30 & 0.16 & 0.27 & 0.43 \\
\hline 12 & 0.08 & 0.89 & 1.58 & 2.55 & 0.10 & 0.57 & 0.67 \\
\hline 13 & 0.14 & 1.06 & 1.24 & 2.45 & 0.12 & 0.45 & 0.57 \\
\hline 14 & 0.10 & 1.26 & 1.03 & 2.38 & 0.14 & 0.37 & 0.51 \\
\hline 15 & 0.91 & 0.94 & 0.61 & 2.46 & 0.18 & 0.22 & 0.41 \\
\hline 16 & 0.05 & 0.99 & 0.92 & 1.96 & 0.10 & 0.33 & 0.44 \\
\hline 17 & 0.50 & 0.48 & 0.97 & 1.95 & 0.10 & 0.35 & 0.45 \\
\hline 18 & 0.07 & 0.58 & 0.81 & 1.46 & 0.07 & 0.29 & 0.36 \\
\hline 19 & 0.00 & 0.17 & 1.99 & 2.16 & 0.02 & 0.72 & 0.73 \\
\hline 20 & 0.23 & 1.25 & 0.22 & 1.69 & 0.15 & 0.08 & 0.23 \\
\hline 21 & 1.52 & 0.00 & 0.47 & 1.99 & 0.15 & 0.17 & 0.32 \\
\hline 22 & 0.62 & 0.12 & 0.74 & 1.48 & 0.07 & 0.27 & 0.34 \\
\hline 23 & 0.83 & 0.02 & 0.23 & 1.08 & 0.08 & 0.08 & 0.17 \\
\hline 24 & 0.50 & 0.01 & 1.14 & 1.65 & 0.05 & 0.41 & 0.46 \\
\hline 25 & 0.40 & 0.10 & 0.24 & 0.74 & 0.05 & 0.09 & 0.14 \\
\hline Subtotal & 22.45 & 29.52 & 56.61 & 107.26 & 5.20 & 20.38 & 25.58 \\
\hline Fraction & $20.93 \%$ & $27.53 \%$ & $52.77 \%$ & & $20.32 \%$ & $79.68 \%$ & \\
\hline
\end{tabular}


Table S4: NOx emission rates for 25 capped accounts in Harris County

\begin{tabular}{|c|c|c|}
\hline Facility Number & Before control & After control \\
\hline & (tons/day) & (tons/day) \\
\hline 1 & 14.20 & 2.84 \\
\hline 2 & 19.76 & 3.95 \\
\hline 3 & 0.45 & 0.09 \\
\hline 4 & 0.15 & 0.03 \\
\hline 5 & 2.20 & 0.44 \\
\hline 6 & 5.55 & 1.11 \\
\hline 7 & 3.57 & 0.71 \\
\hline 8 & 1.66 & 0.33 \\
\hline 9 & 6.59 & 1.32 \\
\hline 10 & 8.21 & 1.64 \\
\hline 11 & 0.17 & 0.03 \\
\hline 12 & 0.42 & 0.08 \\
\hline 13 & 0.04 & 0.01 \\
\hline 14 & 1.44 & 0.29 \\
\hline 15 & 0.00 & 0.00 \\
\hline 16 & 6.68 & 1.34 \\
\hline 17 & 17.29 & 3.46 \\
\hline 18 & 3.82 & 0.76 \\
\hline 19 & 0.49 & 0.10 \\
\hline 20 & 3.44 & 0.69 \\
\hline 21 & 0.22 & 0.04 \\
\hline 22 & 3.02 & 0.60 \\
\hline 23 & 0.34 & 0.07 \\
\hline 24 & 2.16 & 0.43 \\
\hline 25 & 0.24 & 0.05 \\
\hline Total & 102.11 & 20.42 \\
\hline
\end{tabular}




\section{Section S-3: Method for calculating Relative Reduction Factors (RRFs)}

As noted in the paper, RRFs are important to consider because of the role that they play in demonstrating attainment with the National Ambient Air Quality Standard (NAAQS) for ozone, with concentrations averaged over 8-hours. The first step in the attainment demonstration process is to define an ozone "design value" for each monitor in the region. The design value is the fourth highest daily maximum 8-hour averaged ozone concentration for each year, averaged over three years. If the ozone design value is greater than the NAAQS of 85 ppb (concentrations averaged over 8 hours), the monitor is in non-attainment of the standard. To determine if emission reductions will lead to attainment at the monitor, a relative reduction factor (RRF) in ozone concentration is estimated. Photochemical models are used to determine the RRFs that emission reductions will achieve in the vicinity of the monitor. In this work, RRFs associated with trading scenarios were calculated. The ozone concentrations in the trading scenario, relative to the base case attainment demonstration, predicted by the model at monitor locations, are used to estimate the RRF.

$$
\mathrm{RRF}=\left(\text { Ozone concentration }_{\text {trading scenario }}\right) /\left(\text { Ozone concentration }_{\text {Base case }}\right)
$$

Relative reduction factors for ozone are calculated for each site in a non-attainment area that exceeds the NAAQS. This work focused on results for 25 sites that are broadly representative of the entire non-attainment area. The procedure used for estimating the RRFs follows EPA guidance ${ }^{15,16}$ and consisted of the following steps:

1. Determine base case conditions using the modeling episode with emissions and control strategies projected for 2007 (the base case attainment demonstration for the NAAQS for ozone with one-hour averaged concentrations).

2. Determine the sensitivity of RRFs to emission trading scenarios by performing photochemical modeling.

3. For each emission trading scenario and the base case, find the daily maximum 8-hour ozone in an $n \times n$ block of cells ( $n=7$ for a 4-km grid in accordance with U.S. EPA guidance) around each monitor. Repeat for each modeling day.

4. Exclude days when the Base Case daily maximum 8-hour ozone was below 85 ppb.

5. Average the daily maximum 8-hour ozone across days for the Base Case and Trading Scenario, respectively.

6. Calculate the relative reduction factor that will be achieved at each monitor:

$$
\text { RRF }=\text { average Trading Scenario daily maximum ozone concentration }
$$

average Base Case daily maximum ozone concentration

The locations at which the RRFs were calculated are shown in Figures S7 and S8. 


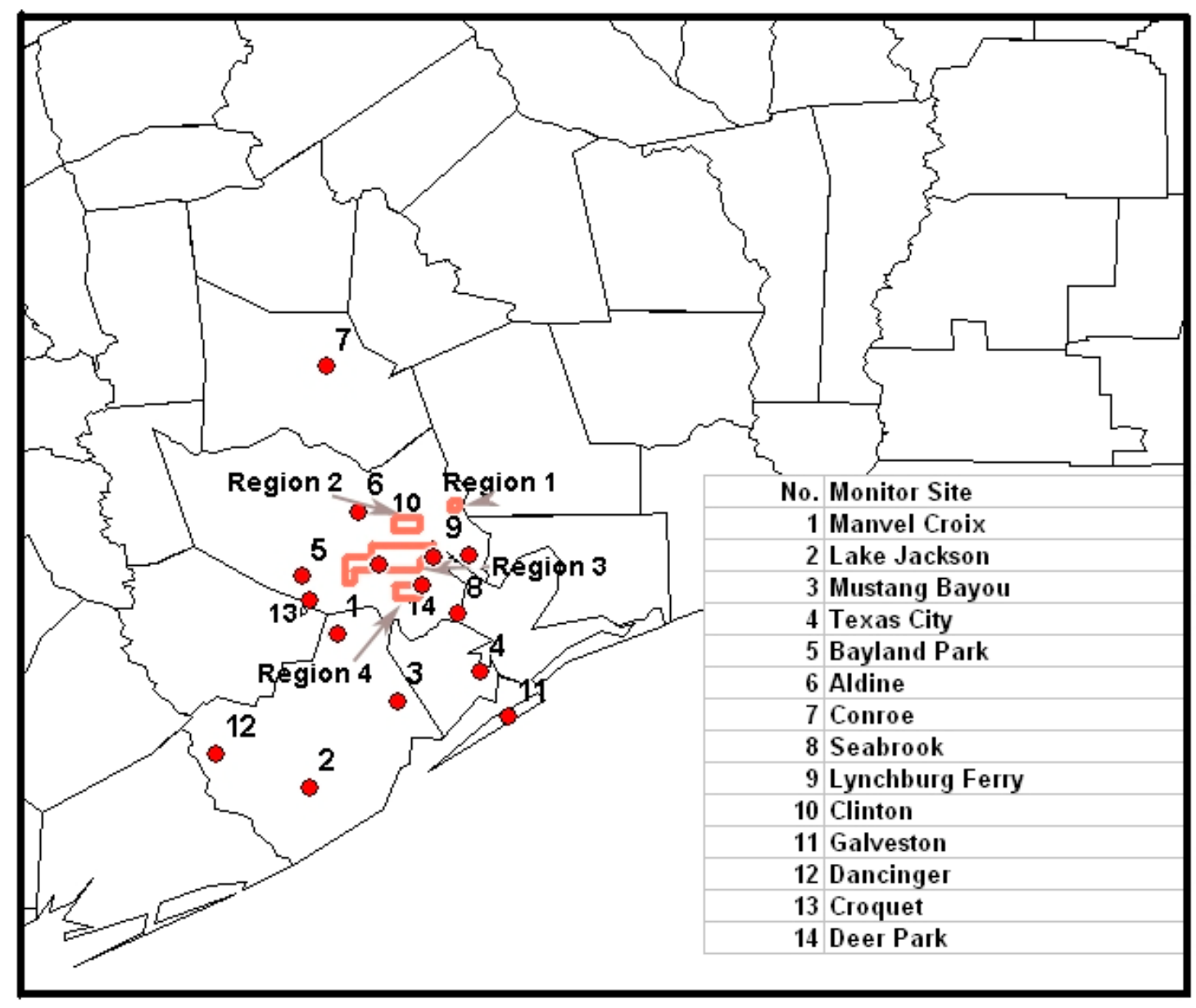

Figure S7. Locations of monitors chosen for RRF calculations. 


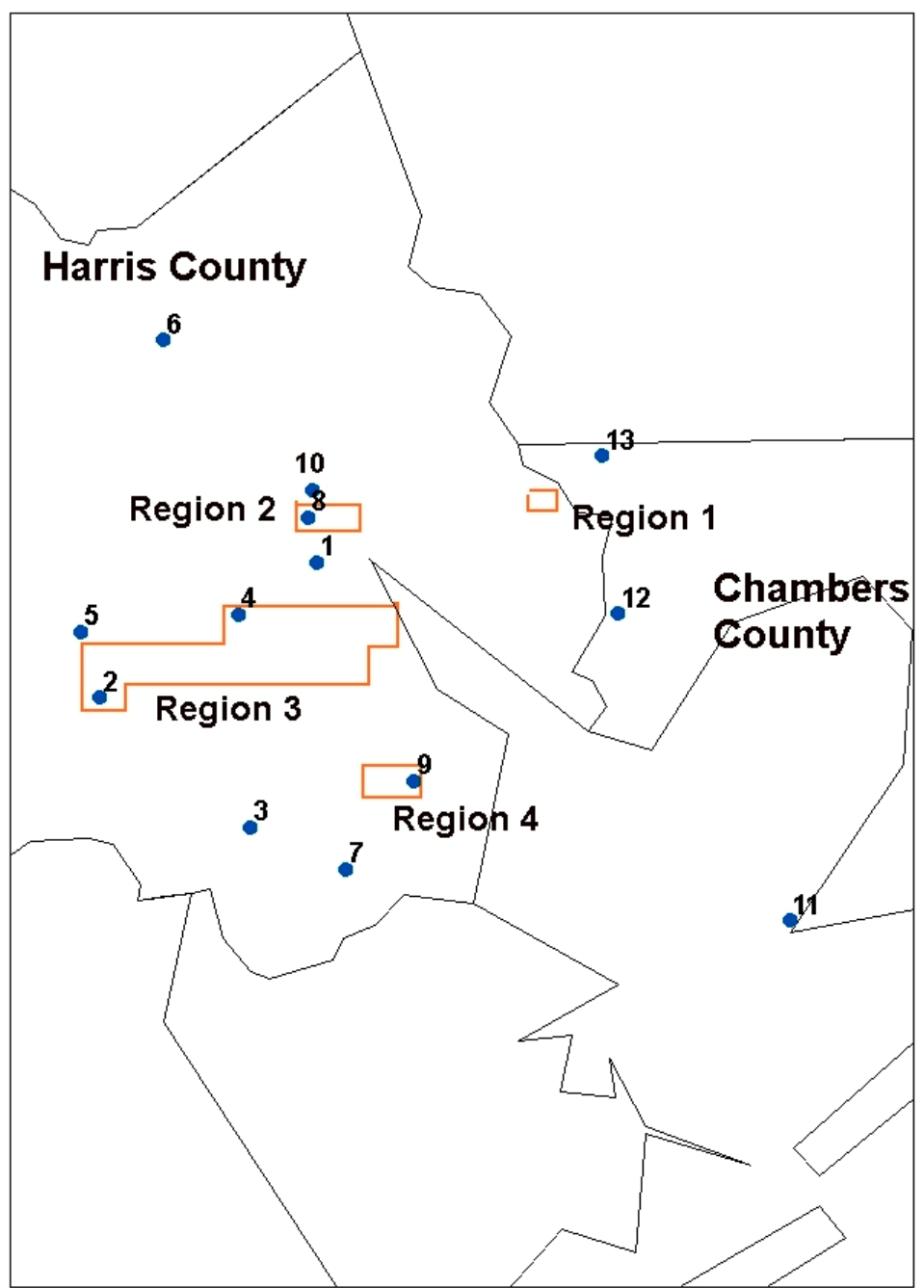

No. Monitor Site 1 Channelview 2 Houston Manchester 3 Ellington Field 4 Haden Road 5 Port of Houston (Fuel Cell) 6 Atascocita 7 Clear Lake High School 8 Sheldon Rd 9 LaPorte 10 Channelview North 11 Smith Point Hawkins Camp 12 E Baytown 13 Mont Belvieu

Figure S8. Locations of additional monitors chosen for RRF calculations. 


\section{Section S-4: Reactivity weighted emission inventories for 25 key accounts}

Reactivity weighted emissions were calculated for each of the 25 emission accounts considered in this work. HRVOC and other-VOC emissions are reported separately. For the other-VOC emissions, after the reactivity weighted emissions were determined, they were converted into equivalent masses of ethylene or propylene, since these two compounds account for $\sim 75 \%$ of the mass of HRVOC emissions. Equivalent masses of ethylene and propylene were calculated by dividing the weighted emissions by the weighting factor (either MIR, EBIR, or MOIR) of ethylene or propylene. For example, the MIR weighted other-VOC emissions for the 25 facilities were 84.5 tons * (g O3/g VOC). Since the MIRs for ethylene and propylene are 9.07 and 11.57 (g O3/g VOC), the other-VOC emissions could be traded for 9.32 and 7.31 tons of ethylene and propylene emissions, respectively. Because the majority ( $75 \%$ ) of HRVOC emissions are ethylene and propylene, the reactivity values for these two species were used to bound the resulting HRVOC equivalent mass.

The original, tradable HRVOC emissions in the 25 accounts, after the HRVOC emissions cap has been put in place, expressed as a MIR reactivity weighted equivalent of ethylene emissions is 5.42 tons/d. If the HRVOC emissions are expressed as propylene equivalents, the emissions are 4.25 tons/d. If all the OVOC emissions are traded for HRVOC allocations, the MIR weighted OVOC emissions can be converted into an additional 9.32 and 7.31 tons $\mathrm{d}^{-1}$ of ethylene and propylene emissions, respectively. This results in total possible emissions of 14.74 and 11.56 tons $\mathrm{d}^{-1}$ of ethylene and propylene emissions, using an MIR based trading system.

Table S5 reports the ethylene and propylene equivalent masses that could be emitted at all facilities, using trading schemes based on MIR, EBIR, and MOIR reactivity weighted emissions. As shown in the Table, if all of the other-VOC emissions are converted into ethylene equivalents and are added to the HRVOC emissions, expressed as ethylene equivalents, trading schemes based on MIR, MOIR and EBIR lead to very similar results. Emissions vary from a low of 13.7 tpd to a high of 14.7 tpd, a difference of 7\%. The results based on propylene equivalents, also shown in Table S5, are different. If all of the other-VOC emissions are converted into propylene equivalents and are added to the HRVOC emissions, expressed as propylene equivalents, trading schemes based on MIR, MOIR, and EBIR lead to very similar results. Emissions vary from a low of 11.0 tpd to a high of 11.6 tpd, a difference of $5 \%$. Based on these results, all of the analyses in the paper used MIR reactivity scales. 
Table S5. HRVOC equivalent mass summary for different reactivity scales

\begin{tabular}{|c|c|c|c|c|}
\hline \multirow{2}{*}{ MIR } & \multicolumn{2}{|c|}{$\begin{array}{l}\text { Emissions as equivalent } \\
\text { ethylene mass (tons } \mathrm{d}^{-1} \text { ) }\end{array}$} & \multicolumn{2}{|c|}{$\begin{array}{l}\text { Emissions as equivalent } \\
\text { propylene mass (tons } \mathrm{d}^{-1} \text { ) }\end{array}$} \\
\hline & & & & \\
\hline HRVOC emissions & 5.42 & & 4.25 & \\
\hline OVOC emissions & 9.32 & & 7.31 & \\
\hline Total MIR based emissions & & 14.74 & & 11.56 \\
\hline \multicolumn{5}{|l|}{ MOIR } \\
\hline HRVOC emissions & 5.47 & & 4.26 & \\
\hline OVOC emissions & 8.95 & & 6.97 & \\
\hline Total MOIR based emissions & & 14.42 & & 11.29 \\
\hline \multicolumn{5}{|l|}{ EBIR } \\
\hline HRVOC emissions & 5.35 & & 4.27 & \\
\hline OVOC emissions & 8.39 & & 6.70 & \\
\hline Total EBIR based emissions & & 13.74 & & 10.97 \\
\hline
\end{tabular}


Section S-5: Impacts of industrial point source VOC emissions on ozone concentrations in base case attainment demonstration

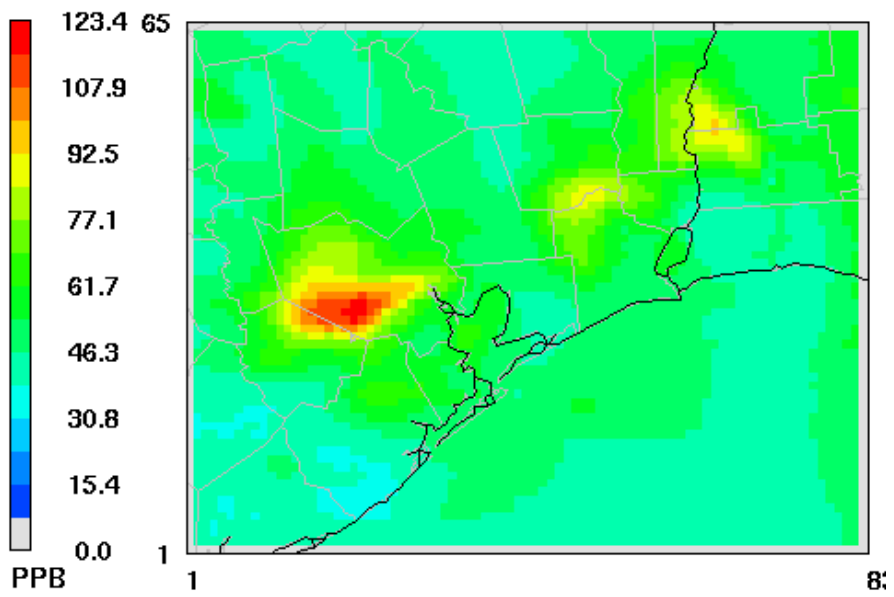

Figure S6. The top panel shows predicted ozone concentrations for the base case attainment demonstration described in the text. The emissions are projected for 2007, after required controls are in place with across-the-board HRVOC reductions (no trading). The meteorology is for the August and September 2000 episode. The ozone concentrations shown are for August 25 at 14:00 hr. The maximum, 1-hour averaged ozone concentration at this hour is $121 \mathrm{ppb}$. The middle panel shows predicted ozone concentrations for the base case attainment demonstration described in the text with all VOC emissions from NEGUs eliminated. The ozone concentrations shown are for August 25 at 14:00 hr. The maximum, 1-hour averaged ozone concentration at this hour is $107 \mathrm{ppb}$. The bottom panel shows the difference between the top and middle panels. The maximum difference is $34 \mathrm{ppb}$. 


\section{Section S-6: $\quad$ Air quality metrics for HRVOC trading between regions}

Table S6. Changes (Trading scenario - Base case attainment demonstration) in air quality metrics based on 1-hour and 8-hour average ozone concentrations between base case attainment demonstration and trading scenarios involving inter-regional trading of HRVOC emissions (non-fugitive); averages and standard deviations are taken over the multiple days of the modeled episode; changes also shown as percentage of the base case value.

\begin{tabular}{|c|c|c|c|c|}
\hline & \multicolumn{2}{|c|}{$\begin{array}{l}1 \text { hour averaged ozone } \\
\text { concentrations }\end{array}$} & \multicolumn{2}{|c|}{$\begin{array}{l}8 \text { hour averaged ozone } \\
\text { concentrations }\end{array}$} \\
\hline Metrics & Average & $\begin{array}{c}\text { diff./ } \\
\text { base case } \\
\text { value }\end{array}$ & Average & $\begin{array}{c}\text { diff./ } \\
\text { base case } \\
\text { value }\end{array}$ \\
\hline $\begin{array}{l}\text { Max. Daily Ozone } \text { ppb } \\
\text { Inter- regional trading into region } 1 \\
\text { Inter- regional trading into region } 2 \\
\text { Inter- regional trading into region } 3 \\
\text { Inter- regional trading into region } 4\end{array}$ & $\begin{array}{c}-0.74 \pm 0.56 \\
-0.20 \pm 0.33 \\
0.15 \pm 0.14 \\
0.14 \pm 0.66 \\
\end{array}$ & $\begin{array}{c}-0.63 \% \\
-0.17 \% \\
0.13 \% \\
0.12 \% \\
\end{array}$ & $\begin{array}{c}-0.23 \pm 0.18 \\
-2.4 \mathrm{E}-02 \pm 2.6 \mathrm{E}-01 \\
5.8 \mathrm{E}-02 \pm 1.0 \mathrm{E}-01 \\
-2.1 \mathrm{E}-02 \pm 1.8 \mathrm{E}-01 \\
\end{array}$ & $\begin{array}{c}-0.26 \% \\
-0.03 \% \\
0.06 \% \\
-0.02 \% \\
\end{array}$ \\
\hline $\begin{array}{l}\text { Area of exceedance } \mathbf{k m}^{2} \\
\text { Inter- regional trading into region } 1 \\
\text { Inter- regional trading into region } 2 \\
\text { Inter- regional trading into region } 3 \\
\text { Inter- regional trading into region } 4 \\
\end{array}$ & $\begin{array}{c}-1.0 \pm 9.2 \\
0.0 \pm 0.0 \\
0.0 \pm 0.0 \\
2.0 \pm 8.0 \\
\end{array}$ & $\begin{array}{l}-0.25 \% \\
0.00 \% \\
0.00 \% \\
0.50 \%\end{array}$ & $\begin{array}{c}-0.11 \pm 0.26 \\
-8.0 \pm 19 \\
0.0 \pm 8.3 \\
4.0 \pm 14\end{array}$ & $\begin{array}{c}-0.62 \% \\
-0.45 \% \\
0.00 \% \\
0.23 \%\end{array}$ \\
\hline $\begin{array}{l}\text { Integrated area of exceedance } \\
\text { Inter- regional trading into region } 1 \\
\text { Inter- regional trading into region } 2 \\
\text { Inter- regional trading into region } 3 \\
\text { Inter- regional trading into region } 4 \\
\end{array}$ & $\begin{array}{l}-13 \pm 32 \\
1.0 \pm 14 \\
1.0 \pm 7.1 \\
1.0 \pm 22 \\
\end{array}$ & $\begin{array}{c}-1.66 \% \\
0.13 \% \\
0.13 \% \\
0.13 \% \\
\end{array}$ & $\begin{array}{l}-43 \pm 51 \\
-11 \pm 27 \\
7.5 \pm 16 \\
4.3 \pm 25 \\
\end{array}$ & $\begin{array}{c}-0.73 \% \\
-0.18 \% \\
0.13 \% \\
0.07 \% \\
\end{array}$ \\
\hline $\begin{array}{l}\text { Population exposure } \\
\text { Inter- regional trading into region } 1 \\
\text { Inter- regional trading into region } 2 \\
\text { Inter- regional trading into region } 3 \\
\text { Inter- regional trading into region } 4\end{array}$ & $\begin{array}{l}-2.9 \mathrm{E}+05 \pm 1.1 \mathrm{E}+06 \\
1.1 \mathrm{E}+05 \pm 4.5 \mathrm{E}+05 \\
3.1 \mathrm{E}+04 \pm 1.2 \mathrm{E}+05 \\
-8.5 \mathrm{E}+04 \pm 3.8 \mathrm{E}+05\end{array}$ & $\begin{array}{c}-2.53 \% \\
0.91 \% \\
0.27 \% \\
-0.73 \%\end{array}$ & $\begin{array}{l}-4.7 \mathrm{E}+05 \pm 1.2 \mathrm{E}+06 \\
-2.6 \mathrm{E}+03 \pm 2.5 \mathrm{E}+05 \\
1.1 \mathrm{E}+05 \pm 3.2 \mathrm{E}+05 \\
2.0 \mathrm{E}+03 \pm 1.1 \mathrm{E}+05\end{array}$ & $\begin{array}{c}-1.70 \% \\
-0.01 \% \\
0.41 \% \\
0.01 \%\end{array}$ \\
\hline
\end{tabular}


Table S7. Average RRF values for each trading scenario at each monitor (same conditions as described in Table S6).

\begin{tabular}{|c|c|c|c|c|}
\hline & $\begin{array}{l}\text { Inter-regional } \\
\text { HRVOC } \\
\text { trading } \\
\text { into Region } 1\end{array}$ & $\begin{array}{l}\text { Inter-regional } \\
\text { HRVOC } \\
\text { trading } \\
\text { into Region } 2\end{array}$ & $\begin{array}{l}\text { Inter-regional } \\
\text { HRVOC } \\
\text { trading } \\
\text { into Region } 3\end{array}$ & $\begin{array}{c}\text { Inter-regional } \\
\text { HRVOC } \\
\text { trading } \\
\text { into Region } 4\end{array}$ \\
\hline Manvel & 0.999 & 1.000 & 1.000 & 1.000 \\
\hline Jackson & 1 & 1 & 1 & 1 \\
\hline Mustang & 1 & 1 & 1 & 1 \\
\hline Texas City & 0.998 & 0.998 & 1.000 & 1.003 \\
\hline Bayland & 0.999 & 1.000 & 1.000 & 0.999 \\
\hline Aldine & 0.999 & 1.000 & 1.000 & 1.000 \\
\hline Conroe & 1 & 1 & 1 & 1 \\
\hline Seabrook & 0.997 & 0.999 & 1.001 & 1.001 \\
\hline Lynchburg & 0.995 & 1.000 & 1.001 & 1.000 \\
\hline Clinton & 0.996 & 1.000 & 1.001 & 0.998 \\
\hline Galveston & 1 & 1 & 1 & 1 \\
\hline Dancinger & 1 & 1 & 1 & 1 \\
\hline Croquet & 1 & 1 & 1 & 1 \\
\hline DeerPark & 0.996 & 0.998 & 1.001 & 1.000 \\
\hline Channelview & 0.997 & 1.005 & 1.000 & 0.998 \\
\hline Houston Manchester & 0.997 & 0.998 & 1.001 & 0.999 \\
\hline Ellington Field & 0.995 & 0.997 & 1.001 & 0.999 \\
\hline Haden Road & 0.995 & 0.999 & 1.001 & 0.999 \\
\hline Port of Houston & 0.997 & 0.999 & 1.001 & 0.998 \\
\hline Atascocita & 0.999 & 1.001 & 1.000 & 1.000 \\
\hline Sheldon Rd & 0.995 & 1.002 & 1.001 & 0.997 \\
\hline LaPorte & 0.995 & 0.998 & 1.001 & 1.000 \\
\hline Channelview North & 0.995 & 1.002 & 1.001 & 0.999 \\
\hline E Baytown & 0.997 & 1.001 & 1.000 & 0.999 \\
\hline Mont Belvieu & 1.000 & 1.003 & 1.000 & 1.000 \\
\hline
\end{tabular}

*Case i: All emissions traded into region i 


\section{Section S-7: Air quality metrics for trading of other-VOCs for HRVOCs}

Table S8. Changes in air quality metrics (Trading scenario - Base case attainment demonstration) associated with each facility converting all other-VOC emissions into HRVOC emissions, based on MIR; averages and standard deviations are taken over the multiple days of the modeled episode; changes also shown as percentage of the base case value.

\begin{tabular}{|c|c|c|c|c|}
\hline \multirow[b]{2}{*}{ Metrics } & \multicolumn{2}{|c|}{$\begin{array}{l}1 \text { hour average ozone } \\
\text { concentration }\end{array}$} & \multicolumn{2}{|c|}{$\begin{array}{c}8 \text { hour average ozone } \\
\text { concentration }\end{array}$} \\
\hline & Average & $\begin{array}{c}\text { (diff./ } \\
\text { base case ) }\end{array}$ & Average & $\begin{array}{c}\text { (diff./ } \\
\text { base case ) }\end{array}$ \\
\hline $\begin{array}{l}\text { Max. Daily Ozone (ppb) } \\
\text { intra-facility trading with emissions } \\
\text { converted to HRVOC allocations based } \\
\text { on facility specific data } \\
\text { intra-facility trading with emissions } \\
\text { converted to HRVOC allocations based } \\
\text { on ethylene MIR } \\
\text { intra-facility trading with emissions } \\
\text { converted to HRVOC allocations based } \\
\text { on propylene MIR. }\end{array}$ & $\begin{array}{c}8.2 \mathrm{E}-02 \pm 1.9 \mathrm{E}-01 \\
0.10 \pm 0.18 \\
-5.7 \mathrm{E}-02 \pm 8.6 \mathrm{E}-02\end{array}$ & $-0.06 \%$ & $9.0 \mathrm{E}-02 \pm 5.0 \mathrm{E}-02$ & $0.10 \%$ \\
\hline $\begin{array}{l}\text { Area of exceedance } \mathbf{k m}^{2} \\
\text { intra-facility trading with emissions } \\
\text { converted to HRVOC allocations based } \\
\text { on facility specific data } \\
\text { intra-facility trading with emissions } \\
\text { converted to HRVOC allocations based } \\
\text { on ethylene MIR } \\
\text { intra-facility trading with emissions } \\
\text { converted to HRVOC allocations based } \\
\text { on propylene MIR. }\end{array}$ & $3.0 \pm 8.7$ & $0.74 \%$ & $\begin{array}{l}10 \pm 15 \\
11 \pm 15\end{array}$ & $0.62 \%$ \\
\hline $\begin{array}{l}\text { Integrated area of exceedance } \mathbf{k m}^{2} \\
\text { intra-facility trading with emissions } \\
\text { converted to HRVOC allocations based } \\
\text { on facility specific data } \\
\text { intra-facility trading with emissions } \\
\text { converted to HRVOC allocations based } \\
\text { on ethylene MIR } \\
\text { intra-facility trading with emissions } \\
\text { converted to HRVOC allocations based } \\
\text { on propylene MIR. }\end{array}$ & $8.5 \pm 26$ & $0.89 \%$ & $\begin{array}{l}35 \pm 47 \\
39 \pm 49\end{array}$ & $0.60 \%$ \\
\hline $\begin{array}{l}\text { Population exposure } \text { ppb*capita }^{*} \text { casions } \\
\text { intra-facility trading with emissions } \\
\text { converted to HRVOC allocations based }\end{array}$ & $1.7 \mathrm{E}+05 \pm 6.5 \mathrm{E}+05$ & $1.44 \%$ & $3.2 \mathrm{E}+05 \pm 8.8 \mathrm{E}+05$ & $1.16 \%$ \\
\hline
\end{tabular}




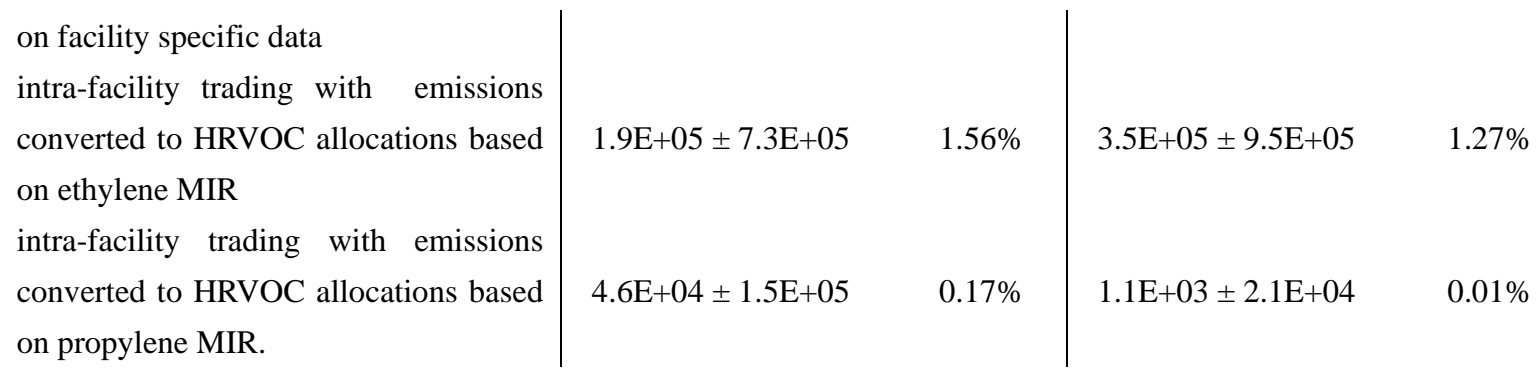

Table S9. Average RRF values for each trading scenario at each monitor; Results are reported for monitoring sites in Houston.

\begin{tabular}{|c|c|c|c|}
\hline Monitor & $\begin{array}{l}\text { RRF for intrafacility other } \\
\text { voc trading with other voc } \\
\text { emission reductions } \\
\text { converted to HRVOC } \\
\text { allocations based on facility } \\
\text { specific MIR }\end{array}$ & $\begin{array}{l}\text { RRF for intrafacility other } \\
\text { voc trading with other voc } \\
\text { emission reductions } \\
\text { converted to HRVOC } \\
\text { allocations based on } \\
\text { ethylene MIR }\end{array}$ & $\begin{array}{l}\text { RRF for intrafacility other } \\
\text { voc trading with other voc } \\
\text { emission reductions } \\
\text { converted to HRVOC } \\
\text { allocations based on } \\
\text { propylene MIR }\end{array}$ \\
\hline Manvel & 1.002 & 1.001 & 1.000 \\
\hline Jackson & 1 & 1 & 1 \\
\hline Mustang & 1 & 1.000 & 1.000 \\
\hline Texas City & 1.001 & 1.001 & 1 \\
\hline Bayland Park & 1 & 1.001 & 1.000 \\
\hline Aldine & 1 & 1.001 & 1.000 \\
\hline Conroe & 1 & 1 & 1 \\
\hline Seabrook & 1.001 & 1.002 & 1.000 \\
\hline Lynchburg & 1.002 & 1.003 & 1.001 \\
\hline Clinton & 1.002 & 1.003 & 1.001 \\
\hline Galveston & 1 & 1 & 1 \\
\hline Dancinger & 1 & 1 & 1 \\
\hline Croquet & 1.001 & 1.001 & 1.000 \\
\hline DeerPark & 1.001 & 1.003 & 1.001 \\
\hline
\end{tabular}


Table S10. Changes (Trading scenario - Base case) in air quality metrics between base case attainment demonstration and trading scenarios involving inter-regional trading of MIR weighted other VOC and HRVOC emissions; averages and standard deviations are taken over the multiple days of the modeled episode; changes also shown as percentage of the base case value.

\begin{tabular}{|c|c|c|c|c|}
\hline & \multicolumn{2}{|c|}{1 hour average concentration } & \multicolumn{2}{|c|}{8 hour average concentration } \\
\hline Metrics & Average & $\begin{array}{c}\text { (diff./ } \\
\text { base case } \\
\text { value) }\end{array}$ & Average & $\begin{array}{c}\text { (diff./ } \\
\text { base case } \\
\text { value) }\end{array}$ \\
\hline \multicolumn{5}{|l|}{ Max. Daily Ozone (ppb) } \\
\hline inter- regional trading into region 1 & $-1.2 \pm 1.1$ & $-1.03 \%$ & $-0.35 \pm 0.29$ & $-0.39 \%$ \\
\hline inter- regional trading into region 2 & $-0.15 \pm 0.57$ & $-0.13 \%$ & $6.3 \mathrm{E}-02 \pm 4.5 \mathrm{E}-01$ & $0.07 \%$ \\
\hline inter- regional trading into region 3 & $0.35 \pm 0.25$ & $0.30 \%$ & $0.14 \pm 0.19$ & $0.15 \%$ \\
\hline inter- regional trading into region 4 & $0.23 \pm 1.2$ & $0.20 \%$ & $-2.4 \mathrm{E}-02 \pm 2.6 \mathrm{E}-01$ & $-0.03 \%$ \\
\hline \multicolumn{5}{|l|}{ Area of exceedance $\left(\mathrm{km}^{2}\right)$} \\
\hline inter- regional trading into region 1 & $-1.0 \pm 21$ & $-0.25 \%$ & $-15 \pm 38$ & $-0.84 \%$ \\
\hline inter- regional trading into region 2 & $2.0 \pm 9.9$ & $0.50 \%$ & $-4.0 \pm 21$ & $-0.23 \%$ \\
\hline inter- regional trading into region 3 & $3.0 \pm 8.7$ & $0.74 \%$ & $7.0 \pm 13$ & $0.39 \%$ \\
\hline inter- regional trading into region 4 & $4.0 \pm 11$ & $0.99 \%$ & $10 \pm 27$ & $0.56 \%$ \\
\hline \multicolumn{5}{|l|}{ Integrated area of exceedance $\left(\mathrm{km}^{2}\right)$} \\
\hline inter- regional trading into region 1 & $-14 \pm 41$ & $-1.78 \%$ & $-71 \pm 69$ & $-1.22 \%$ \\
\hline inter- regional trading into region 2 & $8.0 \pm 37$ & $1.02 \%$ & $19 \pm 91$ & $0.33 \%$ \\
\hline inter- regional trading into region 3 & $9.0 \pm 26$ & $1.15 \%$ & $34 \pm 35$ & $0.58 \%$ \\
\hline inter- regional trading into region 4 & $2.0 \pm 23$ & $0.25 \%$ & $36 \pm 73$ & $0.62 \%$ \\
\hline \multicolumn{5}{|l|}{ Population exposure (ppb*capita) } \\
\hline inter- regional trading into region 1 & $-4.2 \mathrm{E}+05 \pm 1.6 \mathrm{E}+06$ & $-3.63 \%$ & $-6.5 \mathrm{E}+05 \pm 1.6 \mathrm{E}+06$ & $-2.33 \%$ \\
\hline inter- regional trading into region 2 & $3.6 \mathrm{E}+05 \pm 1.5 \mathrm{E}+06$ & $3.14 \%$ & $2.8 \mathrm{E}+05 \pm 1.3 \mathrm{E}+06$ & $0.99 \%$ \\
\hline inter- regional trading into region 3 & $1.6 \mathrm{E}+05 \pm 6.1 \mathrm{E}+05$ & $1.39 \%$ & $3.2 \mathrm{E}+05 \pm 8.5 \mathrm{E}+05$ & $1.16 \%$ \\
\hline inter- regional trading into region 4 & $-9.5 \mathrm{E}+04 \pm 4.6 \mathrm{E}+05$ & $-0.82 \%$ & $8.6 \mathrm{E}+04 \pm 2.3 \mathrm{E}+05$ & $0.31 \%$ \\
\hline
\end{tabular}


Table S11. Average RRF values for each trading scenario at each monitor; trading scenarios involve converting all other VOC emissions in three of the trading regions into HRVOC allocations, and trading those HRVOC emissions into a single region. Results are reported for monitoring sites throughout Houston.

same conditions as described in Table S1).

\begin{tabular}{|c|c|c|c|c|}
\hline & $\begin{array}{l}\text { Inter-regional } \\
\text { HRVOC } \\
\text { trading } \\
\text { into Region } 1\end{array}$ & $\begin{array}{l}\text { Inter-regional } \\
\text { HRVOC } \\
\text { trading } \\
\text { into Region } 2\end{array}$ & $\begin{array}{l}\text { Inter-regional } \\
\text { HRVOC } \\
\text { trading } \\
\text { into Region } 3\end{array}$ & $\begin{array}{l}\text { Inter-regional } \\
\text { HRVOC } \\
\text { trading } \\
\text { into Region } 4\end{array}$ \\
\hline Manvel & 0.998 & 1 & 1.002 & 1.001 \\
\hline Jackson & 1 & 1 & 1 & 1 \\
\hline Mustang & 1 & 1 & 1 & 1 \\
\hline Texas City & 0.998 & 0.998 & 1.002 & 1.006 \\
\hline Bayland & 0.998 & 1 & 1.001 & 0.999 \\
\hline Aldine & 0.998 & 1 & 1.001 & 1.001 \\
\hline Conroe & 1 & 1 & 1 & 1 \\
\hline Seabrook & 0.995 & 0.999 & 1.002 & 1.003 \\
\hline Lynchburg & 0.993 & 1.001 & 1.003 & 1.001 \\
\hline Clinton & 0.994 & 1 & 1.002 & 0.998 \\
\hline Galveston & 1 & 1 & 1 & 1.001 \\
\hline Dancinger & 1 & 1 & 1 & 1 \\
\hline Croquet & 0.999 & 1 & 1.001 & 0.999 \\
\hline DeerPark & 0.994 & 0.998 & 1.004 & 1.004 \\
\hline Channelview & 0.992 & 1.004 & 1.003 & 1 \\
\hline Houston Manchester & 0.995 & 0.997 & 1.002 & 0.999 \\
\hline Ellington Field & 0.993 & 0.996 & 1.005 & 1.002 \\
\hline Haden Road & 0.993 & 1.001 & 1.004 & 1.002 \\
\hline Port of Houston & 0.996 & 1 & 1.003 & 0.998 \\
\hline Atascocita & 0.999 & 1.002 & 1.001 & 1 \\
\hline Sheldon Rd & 0.993 & 1.006 & 1.004 & 0.997 \\
\hline LaPorte & 0.992 & 0.998 & 1.003 & 1.002 \\
\hline Channelview North & 0.995 & 1.010 & 1.001 & 0.997 \\
\hline E Baytown & 0.995 & 1.002 & 1.002 & 0.999 \\
\hline Mont Belvieu & 1.001 & 1.006 & 1 & 1 \\
\hline
\end{tabular}

